\author{
Anna Woźniak-Kot \\ Uniwersytet Warszawski
}

\title{
TELEWIZJA I FILM - KANAEY KOMUNIKACJI I EWANGELIZACJI W ŚWIETLE WYBRANYCH DOKUMENTÓW KOŚCIOŁA KATOLICKIEGO
}

\begin{abstract}
Television and film - channels of communication and evangelization in the light of selected documents of the Catholic Church. The attitude of the Catholic Church towards both film and television has changed over time - from a negative to a positive one. With time, the initial fascination with film on the part of Pope Leo XIII transformed into aversion and hostility: film drew people away from the Church and suppressed religious elements in their minds. A breakthrough came with Pope Pius XII, who did not change the Catholic teachings on the media substantively, but modified the tone of these teachings as well as the perspective on the media. The first television broadcast, after World War II, took place in France in 1948. Afterwards, the Church proposed its own solutions regarding preparation of media messages, formation of creators and education of the media audience. This article is a synthesis of premises within the scope of application, role and use of television and film in the Church's mission. To this end, it contains an analysis of key Church documents dedicated to the media, published after the Second Vatican Council, as well as papal addresses published on World Communication Days.
\end{abstract}

Telewizja i film - kanały komunikacji i ewangelizacji w świetle wybranych dokumentów Kościoła katolickiego. W odniesieniu zarówno do filmu, jak i do telewizji stosunek Kościoła katolickiego zmieniał się - od negatywnego po pozytywny. Początkowa fascynacja filmem Leona XIII przerodziła się z czasem w niechęć i wrogość: film odciągał ludzi od Kościoła i wypierał z ich umysłów pierwiastki religijne. Przełomem była postawa Piusa XII, który nie zmienił merytorycznie katolickiej nauki o mediach, ale zmienił ton nauczania i spojrzenie na media. Pierwsza transmisja telewizyjna po II wojnie światowej miała miejsce 
we Francji w 1948 roku. Po tym wydarzeniu Kościół zaproponował swoje rozwiązania dotyczące przygotowania przekazów medialnych, formacji twórców i edukację odbiorców mediów. Artykuł jest syntetycznym ujęciem założeń co do stosowania, roli i korzystania z telewizji i filmu w misji Kościoła. W tym celu zostały przeanalizowane najważniejsze dokumenty Kościoła na temat mediów, opublikowane po soborze watykańskim II, oraz orędzia papieskie publikowane na Światowe Dni Środków Społecznego Przekazu.

Keywords television, film, media, mass media, truth

telewizja, film, media, środki społecznego przekazu, prawda

Świat mediów stał się współczesnym areopagiem wolności i pluralizmu. Podstawą wszelkiej komunikacji jest „racjonalność źródeł”, a sensem i celem „komunikacja dobra i pozytywnych wartości”. Wszelkie działania środków komunikowania społecznego oraz analiza ich funkcjonowania powinny odbywać się w perspektywie godności odbiorcy, szacunku dla drugiego człowieka, wolności istoty ludzkiej i jej odniesień do Transcendencji ${ }^{1}$.

Kościół jest ustanowiony dla komunikowania (ewangelizacji) ${ }^{2}$. W literaturze przedmiotu znajduje się wiele pozycji analizujących temat wykorzystania środków społecznego przekazu do ewangelizacji. Wiele z nich stara się ująć temat szczegółowo, skupiając się na jednym medium ${ }^{3}$, inne prace analizują dokumenty Kościoła pod kątem celów, zaleceń i powinności mediów wobec człowieka, w świetle nauki Kościoła ${ }^{4}$.

Podstawą tego artykułu będzie całościowa analiza 52 opublikowanych orędzi papieskich, przygotowanych na Światowe Dni Środków Społecznego Przekazu. Ponadto przeanalizowane zostaną trzy dokumenty Kościoła dotyczące celów i powinności mediów w świetle nauczania Kościoła Katolickiego: encyklika Piusa XII o kinematografii, radiu i telewizji Miranda Prorsus (1957), dekret Soboru Watykańskiego II o środkach społecznego przekazywania myśli Inter mirifica (1963) oraz instrukcja duszpasterska Zjednoczenie i postęp o środkach społecznego przekazu (Communio et progressio, 1971).

W niniejszym artykule autorka przeanalizuje całościowo wymienione dokumenty pod kątem zaleceń Kościoła katolickiego dotyczących komunikowania w filmie i telewizji, dodatkowo w kontekście wykorzystania tych mediów w ewangelizacyjnej misji Kościoła. Analizy te mogą pomóc w odpowiedzi na pytanie: jakie kryteria powinno spełniać komunikowanie poprzez telewizję i film, by mogło być ewangelizowaniem. Na podstawie dokumentów Kościoła autorka podejmie próbę znalezienia najważniejszych

1 Por. M. Drożdż, Wstęp, w: Media światem człowieka, red. M. Drożdż, I. Fiut, Kraków-Kielce 2009, s. $9-10$.

${ }^{2}$ Por. A Baczyński, Telewizja jako środek ewangelizacji, w: Kościół a kultura masowa, wybór tekstów F. Adamski, Kraków 1987, s. 57.

3 Por. A Baczyński, Telewizja jako środek ewangelizacji, dz. cyt.

${ }^{4}$ Piszą na ten temat m.in.: A Baczyński, Telewizja jako środek ewangelizacji, dz. cyt.; Kościół a kultura masowa, dz. cyt., K. Pokorna-Ignatowicz, Kościół w świecie mediów, Historia - dokumenty - dylematy, Kraków 2002. 
zaleceń dotyczących komunikowania w odniesieniu do rodzin, ludzi starszych i kobiet oraz sposobów tworzenia kultury przez media. W artykule autorka skupi się na podkreśleniu aksjologicznego wymiaru telewizji i filmu: poszukiwania prawdy w mediach i komunikacji jej poprzez media.

\section{Telewizja W SŁUŻbie CZŁoWiekowi}

Kiedy w 1896 roku w Watykanie pojawiły się ekipy filmowe, papież Leon XIII był żywo zainteresowany nowinkami technicznymi. Jednak po pierwszych zachwytach dla wynalazku pozytywne nastawienie Kościoła zmieniło się radykalnie: Kościół uznał, że film odciąga ludzi od niego. Pierwszym papieżem traktującym media jako nowe zjawisko społeczne był Pius XII. 24 grudnia 1948 roku odbyła się pierwsza transmisja pasterki z katedry Notre Dame w Paryżu, a rok później zostało wyemitowane pierwsze orędzie Piusa XII. To bezprecedensowe wydarzenie zawarzyło na dalszej współpracy Kościoła katolickiego z telewizją.

Pius XII jako pierwszy podjął szereg zagadnień związanych z katolicką nauką o mediach. Interesował się działaniem mediów, starał się, poprzez spotkania, listy i dokumenty, kształtować rzetelne postawy dziennikarskie. Nie stosował w swoim nauczaniu gróźb i pouczeń, odwoływał się raczej do roli mediów w społeczeństwie. Media uważał za dzieło Boże. Przestrzegał, że używanie ich w sposób niezgodny z prawem naturalnym, w sposób obrażający Boga i człowieka, uderza w widza, niszczy go, a w efekcie niszczy całe społeczeństwa. Papież przestrzegał przed używaniem mediów do celów propagandowych i realizacji celów partyjnych. Pius XII apelował także, by w mediach pracowali „ludzie dobrej woli”, uznający autorytet Kościoła w ocenach moralnych i gotowi do zastosowania się do nich ${ }^{5}$.

\subsection{Telewizja W SŁuŻBie PRAWdzie}

Prawda jest podstawą moralną wszelkiej komunikacji - zwłaszcza „poszanowanie

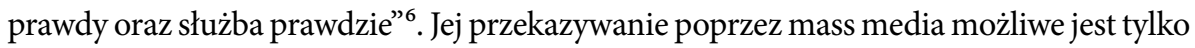
wtedy, gdy są one niezakłamane. Korzystający z nich człowiek staje się autentycznym człowiekiem właśnie „dzięki prawdzie [...], a chrześcijanin - świadkiem i narzędziem ewangelizacji" ${ }^{7}$.

Kościół zachęcał pracujących w mediach do poszukiwania i przekazywania prawdy. Paweł VI wzywał, zwłaszcza chrześcijańskich dziennikarzy, by wszystkie pisane

\footnotetext{
${ }^{5}$ Por. K. Pokorna-Ignatowicz, Kościót w świecie mediów..., dz. cyt., s. 46-47.

${ }^{6}$ Jan Paweł II, Środki społecznego przekazu w stużbie prawdziwego pokoju w świetle encykliki „Pacem in terris". Orędzie na 37. Światowy Dzień Środków Społecznego Przekazu (2003), https://www.paulus.org. pl/230,37-sdssp-jan-pawel-ii-2003 (3.05.2018).

${ }^{7}$ Z. Grocholewski, Rola mediów w Kościele Katolickim, w: Media katolickie: szanse i zagrożenia, red. K. Bieliński, Torun 2010, s. 15.
} 
i wypowiadane przez nich słowa były „wiernym echem Słowa Przedwiecznego [...], Prawdy, która nas uszlachetnia"8. Zagadnieniu prawdy poświęcił całe swoje orędzie napisane w 1972 roku. Skierował w nim do mediów, w tym do telewizji, apel o poszukiwanie prawdy i działanie zgodnie z prawdą. Odwołał się do Boga jako do Najwyższej Prawdy i wzoru postępowania dla ludzi. Nawoływał do szacunku dla porządku rzeczy i wierności normom postępowania, które staną się „gwarancją wierności prawdzie w każdych okolicznościach"”.

Obowiązek głoszenia Prawdy spoczywa na wszystkich mediach. Jak napisał Paweł VI ,prasa, telewizja, kino, radio, teatr, reklama - powinny być w pełni wykorzystane w misji głoszenia światu tak znaczącego orędzia" ${ }^{10}$. W kolejnych latach Benedykt XVI w orędziu z 2008 roku podkreślił, że samo już poszukiwanie prawdy przez człowieka owocuje powstawaniem „wielu inicjatyw wydawniczych, programów czy filmów telewizyjnych wysokiej jakości, w których uznane są i dobrze ukazane prawda, piękno i wielkość osoby ludzkiej, łącznie z jej wymiarem religijnym" ${ }^{11}$.

Społeczność Kościoła dostrzega i podkreśla odpowiedzialność środków komunikowania społecznego za prawdę w przekazywanych przez nie informacjach: „Prawda w mediach oznacza równocześnie, że dobro będzie nazwane zawsze dobrem, a zło złem. [...] Kłamstwo, nieprawda stoją u podstaw przemocy w świecie" ${ }^{12}$. Ta prosta zasada wyjaśnia troskę papieży o przekaz prawdy w mediach i jej wpływ na opinie publiczną. Ta wielka odpowiedzialność za przekaz spoczywa głównie na twórcach mediów: „osoby pracujące $\mathrm{w}$ dziedzinie społecznego przekazu winny czuć się zaangażowane w kształtowanie i szerzenie poglądów zgodnych z prawdą i dobrem" ${ }^{13}$.

\subsection{Telewizja W SeUżBie RozWOJU KUltury}

By wspomóc media w tworzeniu rzetelnego przekazu kultury, Pius XII zaapelował w encyklice Miranda Prorsus o przygotowanie ogólnych zasad, „którymi wynalazki te powinny się rządzić w rozpowszechnianiu na tak wielką skalę wartości kulturalnych i moralnych" ${ }^{14}$. Odbiorca mediów zaś zobligowany jest do tego, by tak korzystać

\footnotetext{
${ }^{8}$ Paweł VI, Środki społecznego przekazu ważnymi elementami cywilizacji. Orędzie na 1. Światowy Dzień Środków Społecznego Przekazu (1967), https://www.paulus.org.pl/266,1-sdssp-pawel-vi-1967 (3.05.2018).

${ }^{9}$ Paweł VI, Środki masowego przekazu w stużbie prawdy. Orędzie na 6. Światowy Dzień Środków Społecznego Przekazu (1972), https://www.paulus.org.pl/261,6-sdssp-pawel-vi-1972 (3.05.2018).

${ }_{10}$ Paweł VI, Środki masowego przekazu a umocnienie i propagowanie wartości duchowych. Orędzie na 7. Światowy Dzień Środków Społecznego Przekazu (1973), https://www.paulus.org.pl/260,7-sdssp-pawel-vi-1973 (3.05.2018).

${ }^{11}$ Benedykt XVI, Środki społecznego przekazu na rozdrożu między gwiazdorstwem a stużbą. Orędzie na 42. Światowy Dzień Środków Społecznego Przekazu (2008), https://www.paulus.org.pl/225,42-sdssp-benedykt-xvi-2008 (3.05.2018).

12 A. Baczyński, Telewizja jako środek ewangelizacji, dz. cyt., s. 204.

${ }^{13}$ Jan Paweł II, Kształtowanie opinii publicznej. Orędzie na 20. Światowy Dzień Środków Społecznego Przekazu (1986), https://www.paulus.org.pl/247,20-sdssp-jan-pawel-ii-1986 (5.05.2018).

${ }^{14}$ Pius XII, Miranda Prorsus. O kinematografi, radiu i telewizji, https: /ekai.pl/dokumenty/encyklika-miranda-prorsus// (5.05.2018).
} 
ze swojej wolności i środków komunikowania społecznego, by jego działanie służyło podstawowemu celowi: ciągłemu ludzkiemu udoskonalaniu ${ }^{15}$.

Sztuka, będąca specyficznie ludzką drogą, powinna być dopełniana przez wiarę, która otwiera człowieka na poznanie najwyższego Bytu. Pomiędzy tymi wymiarami duchowego doświadczenia człowieka zachodzi głęboki związek ${ }^{16}$. Wymaga jednak wysiłku ze strony twórców kultury i mediów, tak by prezentowane poprzez media działania artystyczne, które niejednokrotnie mogą stać się płytką rozrywką, bazującą na niskich instynktach sprzyjających zepsuciu, stawały się drogą do rozwoju odbiorcy, jego wzbogacania i otwarcia na nowe wymiary sztuki i kultury ${ }^{17}$. Niezbędny jest do takiego działania jeden warunek: „ludzie przekazujący informacje winni trzymać się reguł nienagannej etyki zawodowej ${ }^{18 "}$. Niedopuszczalne jest promowanie takich działań w przekazach artystycznych, które nieodpowiedzialnie pobudzają innych „do naśladowania zachowań niegodnych człowieka" ${ }^{19}$.

Twórcom kultury należy dać przestrzeń i wolność do tworzenia nowych dzieł. Papieże w orędziach zalecają jednak, by nie tworzyć sztuki w zupełnym oderwaniu jej od rzeczywistości. Sztuka musi być powiązana $\mathrm{z}$ wartościami, bo „prawdziwa sztuka jest z punktu widzenia ludzkiego jednym z najszlachetniejszych przejawów prawdy ${ }^{20 "}$.

Środki komunikowania społecznego dzięki swoim możliwościom stały się alternatywą dla tradycyjnych sposobów korzystania z dóbr kultury. Stały się one także nowym źródłem kultury, który „umożliwia stosowanie obrazów dźwiękowych i wizualnych”21, mających ogromy wpływ na uczucia i zmysły, szczególnie młodych ludzi.

\subsection{Telewizja W SŁuŻbie pokoju}

Wezwanie do działania na rzecz ludzkości i pokoju, także poprzez środki komunikowania społecznego, kierował Kościół do ludzi mediów już w 1957 roku. W encyklice Miranda Prorsus Pius XII szczególnie podkreślił rolę radia, telewizji i kinematografu, które mają pracować i zmierzać w działaniu „ku chwale Bożej i dobru ludzkości”22. Kilka lat później papież Paweł VI wyjaśnił: „Dzięki tym wspaniałym osiągnięciom techniki $[\ldots]$ człowiek stał się niejako obywatelem świata, jednocześnie aktorem i świadkiem

15 Pius XII, Miranda Prorsus, dz. cyt.

16 Por. Jan Paweł II, Środki społecznego przekazu pomostem pomiędzy wiarą i kulturą. Orędzie na 18. Światowy Dzień Środków Społecznego Przekazu (1984), https://www.paulus.org.pl/249,18-sdssp-jan-pawel-ii-1984 (5.05.2018).

${ }^{17}$ Ks. Andrzej Baczyński zwraca uwagę na fakt, że treść przekazu wiąże się z ogromnym wpływem na pojedynczego człowieka i jego życie oraz życie całych społeczeństw. A zatem treść przekazu prowadzi człowieka i społeczeństwo ku dobru lub złu. Por. A. Baczyński, Telewizja jako środek ewangelizacji, dz. cyt., s. 205-206.

18 Jan Paweł II, Środki społecznego przekazu pomostem pomiędzy wiara i kulturą, dz. cyt.

19 Jan Paweł II, Kino nośnikiem kultury i wartości. Orędzie na 29. Światowy Dzień Środków Społecznego Przekazu (1995), https://www.paulus.org.pl/238,29-sdssp-jan-pawel-ii-1995 (6.05.2018).

${ }^{20}$ Por. Paweł VI, Środki masowego przekazu w służbie prawdy, dz. cyt.

${ }_{21}$ Paweł VI, Środki masowego przekazu i młodzież. Orędzie na 4. Światowy Dzień Środków Społecznego Przekazu (1970), https://www.paulus.org.pl/263,4-sdssp-pawel-vi-1970 (6.05.2018).

22 Pius XII, Miranda Prosus, dz. cyt. 
najbardziej odległych wydarzeń i życia całej ludzkości ${ }^{23}$. Wezwał twórców mediów, rodziców, wychowawców, młodych ludzi oraz „promotorów środków społecznego oddziaływania" do dołożenia wszelkich starań, by treści przekazywane przez nich przyczyniały się do szerzenia pokoju i braterstwa między ludźmi ${ }^{24}$, do takiej służby ludzkości, która ostatecznie uzna ojcostwo Boga, a konsekwencją tego będą braterstwo, sprawiedliwość i pokój ${ }^{25}$.

Niezbędnym narzędziem pokoju jest wolność w mediach i głoszenie prawdy. W 2003 roku Jan Paweł II, pisząc o wolności w środkach komunikowania społecznego, podkreślał, że nie chodzi tylko o wolność polityczną, ale także wolność od zysku i nacisków ludzi zamożnych. Pokój na świecie zależy także w dużej mierze od sumień pracowników mediów oraz ich zdolności służenia prawdzie i człowiekowi: „Środki przekazu ograniczają [...] korzystanie z wolności, jeśli oddalają się od prawdy, rozpowszechniając kłamstwa albo rozbudzając niezdrowe emocjonalne reakcje na wydarzenia" ${ }^{26}$. Ta wielka odpowiedzialność pracowników mediów i ich służba prawdzie to służba ludziom i narodom. „Trzeba dążyć do tego, by wasza działalność doprowadziła do «rozbrojenia umysłów»" 27 pisał papież, podkreślając, że treści medialne wolne od ideologii „przyczyniają się do wzajemnego przenikania się kultur w sposób wolny od nietolerancji i przemocy ${ }^{28}$.

\section{TELEWIZJA JAKO NARZĘDZIE EWANGELIZACJI}

Po soborze watykańskim II i opublikowaniu 4 grudnia 1963 roku dekretu o środkach społecznego przekazywania myśli Inter mirifica Kościół katolicki dostrzegł, że nie można pomijać ogromnej roli środków komunikowania społecznego we współczesnym świecie. Nowe technologie niosą ze sobą nowe możliwości ewangelizacyjne, „których głównym celem ma być rozpowszechnianie i obrona prawdy oraz troska o chrześcijańskie wychowanie ludzkiej społeczności” ${ }^{29}$.

\footnotetext{
${ }^{23}$ Paweł VI, Środki społecznego przekazu ważnymi elementami cywilizacji, dz. cyt.

${ }^{24}$ Por. Paweł VI, Środki społecznego przekazu ważnymi elementami cywilizacji, dz. cyt.

${ }^{25}$ Paweł VI, Środki masowego przekazu a umocnienie i propagowanie wartości duchowych, dz. cyt.

${ }^{26}$ Jan Paweł II, Środki społecznego przekazu w stużbie prawdziwego pokoju w świetle encykliki „Pacem in terris", dz. cyt.

${ }^{27}$ Jan Paweł II, Środki społecznego przekazu w stużbie sprawiedliwości i pokoju. Orędzie na 21. Światowy Dzień Środków Społecznego Przekazu (1987), https://www.paulus.org.pl/246,21-sdssp-jan-pawel-ii-1987 (7.05.2018).

${ }^{28}$ Jan Paweł II, Środki społecznego przekazu w służbie braterstwa i solidarności. Orędzie na 22. Światowy Dzień Środków Społecznego Przekazu (1988), https://www.paulus.org.pl/245,22-sdssp-jan-pawel-ii-1988 (8.05.2018).

${ }^{29}$ Sobór Watykański II, dekret Inter mirifica, https://www.paulus.org.pl/213,inter-mirifica (18.05.2018).
} 


\subsection{Telewizja i geoszenie Dobrej Nowiny}

Papieska Rada ds. Środków Społecznego Przekazu podkreśliła, że środki komunikowania społecznego mogą być pomocne w realizacji misji Kościoła katolickiego: dotarcia do ludzi z orędziem ewangelicznym w najdalszych zakątkach świata ${ }^{30}$, dając również możliwość uczestnictwa w uroczystościach religijnych, pomagając wiernym w utrzymaniu więzi ze swoją wspólnotą, a przede wszystkim dając ludziom możliwość uczestniczenia w życiu żywego Kościoła ${ }^{31}$.

W obliczu narastających konfliktów i pojawiających się w świecie antagonistycznych systemów ideologicznych przekaz Dobrej Nowiny stawał się spoiwem pomiędzy ludźmi i narodami, a środki komunikowania społecznego miały sprzyjać dialogowi i prawdzie, która wyzwala człowieka ${ }^{32}$. Efektem tego było pojawienie się w mediach informacji religijnych, które stawały się coraz popularniejsze wśród odbiorców. Wynikało to nie tylko z rosnącego zainteresowania wartościami religijnymi pojedynczego odbiorcy, ale także było efektem społecznego zapotrzebowania na treści religijne w mediach, „i chociaż ową dialektykę pomiędzy przekazującymi informacje i ich odbiorcami znamionuje niekiedy niekompletność i stronniczość, występuje tu zjawisko pozytywne: religia jest dzisiaj obecna w informacji i w środkach przekazu" ${ }^{33}$.

\subsection{Telewizja a Formacja twórców mediów}

Papieże w orędziach publikowanych na Światowe Dni Środków Społecznego Przekazu nie pomijali zaleceń i przestróg dotyczących twórców mediów. „[...] «media to ludzie». Zarówno wszelkie dobro, jak i manifestujące się często krzykliwie medialne zło są dziełem człowieka [...]"34. Obowiązek ciągłego ulepszania człowieka i grup społecznych przy jednoczesnej jej konfrontacji z prawdziwymi wartościami życia ludzkiego wymaga ciągłej współpracy tych wszystkich, którzy mają wpływ na procesy społecznego przekazu, w tym przede wszystkim twórców mediów ${ }^{35}$. Widz, czytelnik, odbiorca treści medialnych

${ }^{30}$ Papieska Komisja do Spraw Środków Społecznego Przekazu, Instrukcja duszpasterska Zjednoczenie $i$ postęp o środkach społecznego przekazu, zredagowana na polecenie Drugiego Watykańskiego Soboru Powszechnego, w: Kościół a kultura masowa, dz. cyt., s. 308-309.

${ }^{31} \mathrm{Na}$ temat roli radiofonii i telewizji w wypełnianiu misji Kościoła katolickiego pisał Piotr Wiśniewski. W publikacji zawarł najważniejsze informacje dotyczące posługiwania się przez Kościół katolicki radiofonią i telewizją. Por. P. Wiśniewski, Radiofonia i telewizja, narzędzia służące realizacji misji Kościoła. Prawo i praktyka $w$ Polsce 1989-2008, Lublin 2010, s. 29-51.

32 Por. Paweł VI, Środki masowego przekazu w służbie jedności ludzkiej. Orędzie na 5. Światowy Dzień Środków Społecznego Przekazu (1971), https://www.paulus.org.pl/262,5-sdssp-pawel-vi-1971 (10.05.2018).

${ }^{33}$ Jan Paweł II, Religia w środkach przekazu. Orędzie na 23. Światowy Dzień Środków Społecznego Przekazu (1989), https://www.paulus.org.pl/244,23-sdssp-jan-pawel-ii-1989 (10.05.2018).

${ }^{34}$ M. Drożdż, Media przestrzenią dialogu z człowiekiem. Inspiracje soborowe w myśli Jana Pawła II, w: Inter mirifica. Dziedzictwo i perspektywy, red. A. Baczyński, M. Drożdż, M. Legan, Kraków 2013, s. 86.

${ }^{35}$ Paweł VI, Środki społecznego przekazu: korzyści - niebezpieczeństwa - odpowiedzialność. Orędzie na 11. Światowy Dzień Środków Społecznego Przekazu (1977), https://www.paulus.org.pl/256,11-sdssp-pawel-vi-1977 (10.05.2018). 
powinien nawiązać dialog z twórcami mediów. By było to możliwe, widz musi nauczyć się trudnego języka mediów. Umiejętność rozmowy z twórcami zaowocuje wyborami odpowiednich treści i właściwymi typami przekazu przez ludzi mediów ${ }^{36}$.

W 1988 roku papież Jan Paweł II podkreślił w swoim orędziu, że pracownicy mediów zdają sobie sprawę i wiedzą, jak niewłaściwy przekaz medialny może wpłynąć na wypaczenie braterstwa i wzajemnego szacunku między narodami: „winni oni [pracownicy mediów] poszczególnym ludziom i wspólnotom przekazywać obrazy, które przyczyniają się do wzajemnego przenikania się kultur w sposób wolny od nietolerancji i przemocy, sprzyjający jedności” ${ }^{37}$.

Szczególne miejsce w formacji twórców środków komunikowania społecznego zajmują pracownicy telewizji - „dyrektorzy i kierownicy, producenci i reżyserzy, autorzy, reporterzy i dziennikarze, osoby występujące przed kamerami i personel techniczny"38. Kościół przestrzega przed przekazywaniem tego, co może szkodzić trwałości i szczęściu rodziny, czyli „pornografią i przemocą, propagowaniem rozwodów lub aspołecznych postaw wśród młodzieży" ${ }^{39}$. Pracownicy telewizji nie są bezradni wobec niebezpieczeństw związanych z przekazem niewłaściwych treści - wychodząc naprzeciw ich potrzebom, Kościół otwiera się na nich i zachęca, by korzystali z posługi duszpasterskiej Kościoła, która polega na formacji etycznej i moralnej pracowników mediów.

\subsection{TElewizJA A FORMACJA ODBIORCów}

Kościół dostrzega potrzebę formacji twórców mediów, jak i edukację odbiorców ${ }^{40}$, którym zaleca się roztropność i czujność ${ }^{41}$. W opublikowanym dokumencie soborowym Inter mirifica już w rozdziale pierwszym czytamy: „Kościół katolicki [...] uważa [...] za swój obowiązek [...] uczyć ludzi właściwego korzystania z nich"². Roztropność i czujność powinny być szczególnie istotne dla rodziców i wychowawców, którzy mają wpływ na to, jakie programy oglądają dzieci i młodzież. Do edukowania młodego pokolenia związanego z odpowiedzialnym korzystaniem z mediów powołani są nie tylko rodzice, Kościół rozszerza ten obowiązek, powołując do edukowania młodzieży także wychowawców oraz wszystkich odbiorców mediów, w tym wspólnoty, parafie ${ }^{43}$.

${ }^{36}$ Por. Paweł VI, Telewizja w rodzinie: kryteria właściwego wyboru programów, dz. cyt.

${ }^{37}$ Jan Paweł II, Środki społecznego przekazu w służbie braterstwa i solidarności, dz. cyt.

38 Jan Paweł II, Telewizja w rodzinie: kryteria właściwego wyboru programów, dz. cyt.

39 Jan Paweł II, Telewizja w rodzinie: kryteria właściwego wyboru programów, dz. cyt.

${ }^{40}$ Ksiądz Marek Lis podkreśla, że bez edukacji medialnej społeczeństwo może stać się ofiarą czwartej władzy. Bez odpowiedniej wiedzy widz będzie bezkrytycznie przyswajać treści medialne, często nakłaniające odbiorców językiem perswazji do działań bezrefleksyjnych. M. Lis, Edukacja medialna: ważny postulat „Inter mirifica", w: Inter mirifica. Dziedzictwo i perspektywy, dz. cyt. s. 45-46.

41 Por. Pius XII, Miranda Prosus, dz. cyt.

42 Sobór Watykański II, dekret Inter mirifica, 3.

${ }^{43}$ Więcej: Sobór Watykański II, dekret Inter mirifica, 15; Papieska Komisja do Spraw Środków Społecznego Przekazu, Instrukcja duszpasterska Zjednoczenie i postęp..., dz. cyt., 67-70, 107; Paweł VI, Odbiorcy środków społecznego przekazu, ich oczekiwania, prawa i obowiązki. Orędzie na 12. Światowy Dzień Środków Społecznego Przekazu (1978), https://www.paulus.org.pl/255,12-sdssp-pawel-vi-1978 (15.05.2018). 
By wychowywać młode pokolenia do korzystania z mediów, Kościół zaleca tworzenie specjalnych kierunków na uniwersytetach ${ }^{44}$. Dobrze wyedukowany młody człowiek może stać się także nauczycielem dla innych młodych ludzi, niejednokrotnie skuteczniejszym niż dorosły.

Dzieci bezbronne wobec złych treści dostarczanych przez mass media nie potrafią ocenić ich zgubnego wpływu od razu. „To ludzie dorośli - rodzice, wychowawcy, pracownicy środków przekazu - mają obowiązek i są w stanie pomóc mu je odkryć" ${ }^{45}$. Zdeformowane młode pokolenia nie tylko nie będą krytycznymi odbiorcami treści a mediach, ale także nie będą potrafiły budować świata zgodnego z wartości duchowymi. Tylko wspólne wychowanie do odpowiedzialnego korzystania z mediów może przyczynić się do wychowania świadomych młodych pokoleń, które budować będą świat braterstwa i pokoju w duchu Ewangelii.

Co do dorosłych odbiorców - ważne jest, by ich edukacja medialna dokonywała się w powiązaniu z ewangelizacją i by „wszyscy, którzy ich używają, znali zasady porządku moralnego i ściśle je w tej dziedzinie wcielali w życie" ${ }^{46}$. Poznanie tych zasad pozwoli na głębszą analizę istoty ludzkiej oraz dostrzeganie zła moralnego w przekazach medialnych. Ważne jest także, by dorośli odbiorcy mediów uczestniczyli w sympozjach, wykładach, dyskusjach. Wszelkie zalecenie Kościoła sprowadzają się do stwierdzenia, że dopiero odpowiednio przygotowany odbiorca, młody czy dojrzały, w pełni i świadomie może korzystać $\mathrm{z}$ treści komunikowanych przez media ${ }^{47}$.

\section{Telewizja A ASPeKty SPOEECZne}

Środki komunikowania społecznego z roku na rok zagarniają coraz to większe obszary ludzkiej wolności. Już w 1970 roku papież zauważył, że nie tylko wkradają się w życie człowieka, ale także starają się zastąpić ludzi, którzy przekazywali do tej pory młodym pokoleniom podstawową wiedzę: zastępują rodziców, nauczycieli czy parafie: „środki społecznego przekazu spełniają coraz większą i szerszą rolę na polu wychowania" ${ }^{48}$.

${ }^{44}$ „We wszystkich szkołach katolickich, seminariach, jak również w kołach apostolstwa świeckich”. Por. Sobór Watykański II, dekret Inter mirifica, 16.

${ }^{45}$ Jan Paweł II, Środki społecznego przekazu $w$ służbie ochrony i rozwoju dziecka $w$ rodzinie $i$ w społeczeństwie. Orędzie na 13. Światowy Dzień Środków Społecznego Przekazu (1979), https://www.paulus.org. pl/254,13-sdssp-jan-pawel-ii-1979 (15.05.2018).

${ }^{46}$ Sobór Watykański II, dekret Inter mirifica, 4.

${ }^{47}$ Por. Papieska Komisja do Spraw Środków Społecznego Przekazu, Instrukcja duszpasterska Zjednoczenie i postęp..., dz. cyt.

${ }^{48}$ Papieska Komisja do Spraw Środków Społecznego Przekazu, Instrukcja duszpasterska Zjednoczenie i postęp..., dz. cyt. 


\subsection{TElewizJA A RODZINA}

Wpływ mediów na dzieci, młodzież i rodzinę z każdym rokiem staje się ważniejszy i coraz bardziej niepokojący ${ }^{49}$. Już w 1980 roku Jan Paweł II podkreślił w swoim orędziu, że trudno jest znaleźć dom, w którym nie byłoby telewizora. Wraz z tym dodatkowym meblem w mieszkaniu pojawiają się w nim nowi jego mieszkańcy: aktorzy, konferansjerzy, ale także politycy i inne osoby mające wpływ na rodzinne rozmowy i wychowanie nowych pokoleń. W domach zaczynają "gościć” ludzie reprezentujący nowe zawody, naukowcy informujący o nowych technologiach i ideologiach, ludzie reprezentują inne kultury i narodowości ${ }^{50}$.

Przedstawiane przez niech poglądy, przemyślenia, propozycje, podawane są przez media w bardzo atrakcyjny i przystępny sposób i podstępnie próbują przejąć rolę rodziców w trudnym procesie wychowania młodego pokolenia. Wkradając się w umysły i serca młodych ludzi, wtłaczają im, poprzez sugestywne obrazy i dźwięki, nowe wartości egzystencjalne, często inne niż te, które proponuje młodemu pokoleniu rodzina wychowująca swoje dzieci w duchu wartości chrześcijańskich ${ }^{51}$.

Stąd wezwanie kolejnych papieży skierowane do rodziców, by uczyli swoje dzieci krytycznego korzystania z telewizji. Zezwalając dzieciom na korzystanie z mediów, rodzice sami powinni poznać programy (czy treści przedstawione w programach będą pozytywnie wpływać na rozwój osobowy, moralny i religijny ich dzieci), czytać recenzje, a mając wątpliwości, powinni kontaktować się z odpowiednimi organizacjami religijnymi. Ponadto rodzice jako pierwsi nauczycie mają obowiązek rozmawiać ze swoimi dziećmi na temat telewizji „ucząc ich kontrolowania ilości i jakości oglądanych programów oraz dostrzegania i oceny moralnych wartości, które stanowią ich podłoże" ${ }^{52}$.

W duchu szczególnej troski o rodzinę Jan Paweł II napisał orędzie na temat wpływu mediów na wychowanie w rodzinie w 2004 roku. Podkreślił w nim, że dorośli, rodzice i pracownicy mediów są powołani do budowania takiego przekazu medialnego, by szanował on prawdę i godność człowieka. Ze względu na różnorodność tematów proponowanych przez środki komunikowania społecznego to rodzice powinni ustalać, jakie programy mogą oglądać ich dzieci i ile czasu poświęcają na ich oglądanie. Powinni także wpływać na ludzi mediów i dziennikarzy, by treści przygotowywane w mediach były zgodnie z wartościami chrześcijańskimi. Papież zwraca uwagę, że często treści

${ }^{49}$ Warto przytoczyć kilka opinii specjalistów dotyczących negatywnego wpływu spędzania wolnego czasu przed telewizorem w rodzinie. Jadwiga Komorowska w artykule Telewizja a wychowanie w rodzinie i zdrowie psychiczne dziecka zwraca uwagę na kilka aspektów: zbyt długie przesiadywanie przed telewizorem pozbawia dziecko ruchu, osłabia jego system nerwowy, powoduje pośpiech w odrabianiu lekcji (by mieć więcej czasu na oglądanie telewizji), pogłębia niesystematyczność i zaniedbania w obowiązkach szkolnych i domowych, sprzyja rozluźnianiu więzi rodzinnych i szkolnych, deformuje wiedzę dziecka na temat świata dorosłych. Zob. J. Komorowska, Telewizja a wychowanie w rodzinie i zdrowie psychiczne dziecka, w: Kościót a środki społecznego przekazu, Warszawa1990, s. 114-126.

${ }^{50}$ Por. Jan Paweł II, Rodzina wobec środków społecznego przekazu. Orędzie na 14. Światowy Dzień Środków Społecznego Przekazu (1980), https://www.paulus.org.pl/253,14-sdssp-jan-pawel-ii-1980 (18.05.2018).

${ }^{51}$ Por. Jan Paweł II, Rodzina wobec środków społecznego przekazu, dz. cyt.

52 Jan Paweł II, Telewizja w rodzinie: kryteria właściwego wyboru programów, dz. cyt. 
kolportowane w mediach przedstawiają rodzinę życzliwe i w sposób godny, zdarza się jednak, że obraz rodziny kreowany w niektórych mass mediach odbiega od prawdziwego wizerunku, skupiając się na przedstawianiu jej jako związku pełnego konfliktów, krzywd i niedomówień. Bez komentarza pozostawia się tematy o związkach pozamałżeńskich, antykoncepcji, aborcji i homoseksualizmie ${ }^{53}$.

\subsection{Telewizja A OSOBy STARSZE}

Większość orędzi pisanych na Światowy Dzień Środków Społecznego Przekazu kierowana była do rodzin, pracowników mediów, młodzieży. Jednak orędzie opublikowane przez Jana Pawła II w 1982 roku w całości skierowane było do ludzi starszych. Ojciec święty wspomniał o trudnej sytuacji ludzi w podeszłym wieku, o braku opieki, samotności, często nędzy i życiu w niedostatku. Zachęcał ludzi dobrej woli do wspierania tych wszystkich ruchów, które poprzez swoją działalność starają się pomagać ludziom w podeszłym wieku. W orędziu Jan Paweł II zachęcał, by ludzie starsi włączyli się czynnie w życie rodzinne, by dzielili się swoją wiedzą z młodym pokoleniem.

Dzięki środkom masowego przekazu ludzie starsi mogą przeżywać swoje życie duchowe w bliskości z Bogiem: dzięki transmisjom telewizyjnym i radiowym mogą uczestniczyć w mszach świętych i nabożeństwach. Odbiorcy w podeszłym wieku to znaczna część widzów, słuchaczy i czytelników, dlatego też twórcy mediów powinni troszczyć się o właściwy przekaz dla tej grupy społecznej: oferta programowa dla ludzi starszych powinna składać się nie tylko z materiałów informacyjnych, ale także powinna sprzyjać formacji duchowej" ${ }^{54}$.

\subsection{TEleWizJA A PROMOCJA Kobiety}

Jan Paweł II w orędziach na Światowy Dzień Środków Społecznego Przekazu poruszał także temat wizerunku kobiet $\mathrm{w}$ mediach. W orędziu z 1996 roku odniósł się w szczególny sposób do sytuacji kobiet w czasach dominacji mediów. Lekceważenie macierzyństwa, dyskryminacja społeczna i ekonomiczna, nierówność małżonków w prawach rodziny - to tylko niektóre z kwestii, o których wspomniał papież. W orędziu nie tylko zaapelował o poszanowanie praw kobiet, ale przede wszystkim podkreślił zalety kobiet $\mathrm{i}$ ich rolę $\mathrm{w}$ społeczeństwie. Zaapelował o promocję kobiet $\mathrm{i}$ ich wielkiego znaczenia dla rodziny ludzkiej: „[...] kobiety potrafią wnieść w każdą dziedzinę życia [...] istotny element kobiecego geniuszu, jakim jest obiektywność osądu połączona

${ }^{53}$ Por. Jan Paweł II, Media w rodzinie: ryzyko i bogactwo. Orędzie na 38. Światowy Dzień Środków Społecznego Przekazu (2004), https://www.paulus.org.pl/229,38-sdssp-jan-pawel-ii-2004 (16.05.2018).

${ }^{54}$ Por. Jan Paweł II, Środki społecznego przekazu a problemy ludzi starszych. Orędzie na 16. Światowy Dzień Środków Społecznego Przekazu (1982), https://www.paulus.org.pl/251,16-sdssp-jan-pawel-ii-1982 (18.05.2018). 
ze zdolnością rozumienia głębokich uwarunkowań każdej relacji międzyludzkiej" ${ }^{55}$. Papież podkreślił, że kobiety powinny zajmować kierownicze stanowiska, także w mediach, nie po to, by konkurować z mężczyznami, ale po to, by wnosić ten pierwiastek kobiecy w środowiska, także medialne.

W tym wyjątkowym orędziu papież położył szczególny nacisk na poszanowanie godności kobiety w programach telewizyjnych i reklamie. Nie jest to jednak możliwe bez większego zaangażowania samych kobiet $\mathrm{w}$ pracę mediów, modlitwę za ich twórców oraz współpracę z pracownikami środków komunikowania.

\section{Film a WyChowanie}

Zanim telewizja stała się najpotężniejszym medium XX wieku, najbardziej wpływowe było kino. „Film kinowy stał się pierwszym rodzajem przemysłu kultury, inaczej show-biznesu, źródłem wielkich zysków z branży medialnej" ${ }^{56}$. Już z pierwszych dokumentów opublikowanych przez Kościół dotyczących mediów wynikało, że film stał się jednym z najważniejszych środków komunikowana myśli i dlatego też podlegał specjalnym regulacjom ze strony Kościoła katolickiego ${ }^{57}$. W dokumentach apelowano, by tworzenie filmów, zwłaszcza filmów dokumentalnych, odbywało się zawsze w perspektywie widza, który dzięki filmowi może się rozwijać, kształcić, ale także - stawać się lepszym ${ }^{58}$.

\subsection{FilM W SŁUŻBIE CZŁOWIEKOWI}

Dostrzeżenie ogromnego potencjału edukacyjnego w filmie nastąpiło już w latach 50. XX wieku, kiedy papież Pius XII dostrzegł, że film, zwłaszcza film edukacyjny i telewizja szkolna, otwierają „nieoczekiwane możliwości nie tylko dla młodzieży, ale także dorosłych" ${ }^{59}$. Film, który mógł wspierać edukację społeczeństwa, mógł spełniać swoją funkcję tylko wtedy, kiedy nie sprzeciwiał się nienaruszalnym prawom Kościoła

${ }^{55}$ Jan Paweł II, Współczesne środki przekazu w służbie postępu kobiety w społeczeństwie. Orędzie 30. Światowy Dzień Środków Społecznego Przekazu (1996), https://www.paulus.org.pl/237,30-sdssp-jan-pawel-ii-1996 (18.05.2018).

56 T. Goban-Klas, Media i komunikowanie masowe. Teorie $i$ analizy prasy, radia, telewizji $i$ Internetu, Warszawa 2009, s. 21.

57 Papież Pius XII w dokumencie Miranda Prorsus w 1957 pisał: „Nie można wątpić, że z tego zadziwiającego postępu, jaki technika naszych czasów wniosła do filmu, radia i telewizji, mogą wynikać olbrzymie korzyści, ale też i bardzo wielkie niebezpieczeństwa. [...] Dostępne dzisiaj, rzecz można każdemu, środki techniczne wywierają na człowieka potężny wpływ, prowadzący go «zarówno do królestwa światła, do tego, co szlachetne, co piękne, jak i do królestwa ciemności i zepsucia», na pastwę niepohamowanych instynktów, zależnie od tego, czy widowisko ukazuje i akcentuje jeden czy drugi aspekt”. Pius XII, Miranda Prorsus, 18.

58 Por. Pius XII, Miranda Prorsus, 85

59 Por. Pius XII, Miranda Prorsus, 56. 
i rodziny na polu wychowania młodzieży ${ }^{60}$. Pomocne dla katolików miały być powołane przez Piusa XI „stałe urzędy kontroli, których zadaniem byłoby popieranie wartościowych filmów, ocenianie innych i przekazywanie swych ocen do wiadomości kapłanom i wiernym oraz kierownictwo działalnością katolików w dziedzinie kinematografii”" ${ }^{61}$.

Prasa, radio, telewizja, film - wszystkie te media powinny przede wszystkim służyć sprawie podstawowych praw i obowiązków człowieka ${ }^{62}$. Ufna współpraca między narodami, dialog międzyludzki, wszelkie działania promujące współpracę i wzajemną pomoc stają się narzędziami do tworzenia nie tylko właściwego przekazu, poprzez który środki komunikowania społecznego wypełniają swoją misję, ale także przyczyniają się do budowania pogłębionych relacji międzyludzkich. Wobec tematów trudnych, wobec wojen, przemocy i niesprawiedliwości środki masowego przekazu nie mogą pozostać obojętne.

Korzystanie ze środków społecznego przekazu powinno być nie tylko bezrefleksyjnym otwarciem gazety, naciśnięciem przycisku na radioodbiorniku czy kupieniem biletu do kina. Korzystanie $\mathrm{z}$ mediów powinno być poprzedzone przygotowaniem odbiorcy do umiejętnego korzystania z mediów i wyrobieniem w odbiorcach współodpowiedzialności za siebie i twórców mediów. Kościół zaleca, by już od najmłodszych lat uczyć się języka mediów, języka filmu i widowisk. To, „co jest pokazywane na ekranie kina, w telewizji, lub to, co głośnik ogłasza, człowiek winien trzeźwo osądzać, a nie, jak to się często zdarza, poddawać się biernie ich urzekającej sile"63, pisał w encyklice Miranda Prorsus Pius XII.

\subsection{Film A ZAgrożenia}

Wraz z rozwojem kinematografii i telewizji, w której emitowane były także filmy, pojawił się temat reklamy filmowej. Zauważył to już w 1977 roku Paweł VI, który podkreślił, że reklama filmowa rani człowieka, narusza spokój sumień i niszczy zgodę pomiędzy ludźmi. Dlatego też potrzeba, by ludzie Kościoła katolickiego, zarówno osoby duchowne, jak i świeckie, włączyły się w dialog ze środowiskami promującymi i produkującymi reklamę filmową, by skłonić ich do zaprzestania naruszania godności człowieka i zasad porządku moralnego ${ }^{64}$.

W dokumencie Communio et progressio czytamy, że nie można zrozumieć życia ludzkiego bez przedstawienia go całościowo: pokazując także gwałtowność natury ludzkiej, która objawia się agresją, walką i zbrodnią. Dlatego pojawia się pytanie: czy film prezentujący takie sceny i człowieka popełniającego występki jest filmem dobrym? Film o takiej tematyce, jak i każde inne dzieło artystyczne, podlega tym samym zasadom: należy rozróżnić pomiędzy wartością dzieła a dobrem moralnym i tworzyć filmy tak,

60 Pius XII, Miranda Prorsus, 56.

61 Pius XII, Miranda Prorsus, 78.

${ }^{62}$ Por. Paweł VI, Środki społecznego przekazu wobec podstawowych praw i obowiązków człowieka. Orędzie na 10. Światowy Dzień Środków Społecznego Przekazu (1976), https://www.paulus.org.pl/257,10-sdssp-pawel-vi-1976 (20.05.2018).

63 Pius XII, Miranda Prorsus, 65.

${ }^{64}$ Paweł VI, Środki społecznego przekazu: korzyści - niebezpieczeństwa - odpowiedzialność, dz. cyt. 
by przyczyniały się do wzrostu człowieka, nie zaburzając jego poczucia wartości, oraz by przedstawione treści nie zaciemniały prawdziwego obrazu świata ${ }^{65}$.

W miarę rozwoju środków komunikowania społecznego papieże dostrzegali zgubny wpływ mediów na człowieka, który zaczął korzystać z nich nie tylko, by poszerzyć swoją wiedzę, ale głównie dla rozrywki i spędzenia z mediami wolnego czasu. Treści publikowane w mediach, zwłaszcza emitowane w telewizji, także w kinie, stawały się coraz bardziej brutalne - przedstawiając nieprawdziwy obraz świata wypełniony kłamstwem, przemocą i seksem. Dlatego „uzdrowienie społecznego przekazu i powrót do szlachetnych celów jest zadaniem wszystkich" ${ }^{\prime 6}$.

Ważne jest także, by rozwijała się współpraca ośrodków katolickich z różnymi ośrodkami przekazywania kultury. Na głoszenie orędzia religijnego jest także miejsce w komiksach i filmach animowanych, także innych publikacjach sprzyjających dobrej rozrywce. Tylko zaangażowanie zarówno twórców, jak i środowisk katolickich promujących określone wartości, będzie sprzyjać powstawaniu wartościowych dzieł kultury, które będą sprzyjać rozwojowi człowieka ${ }^{67}$.

\section{Film a kUltura}

„Wartości ludzkie i chrześcijańskie, zasługujące na uwagę i pochwałę, można znaleźć nie tylko w filmach odwołujących się bezpośrednio do tradycji chrześcijańskiej, ale także powstających w innych kręgach kulturowych i religijnych, co potwierdza znaczenie kina jako przestrzeni wymiany kulturowej" napisał Jan Paweł II w orędziu na Światowy Dzień Komunikowania Społecznego $1995 \mathrm{roku}^{68}$. Zanim pojawiła się telewizja, z jej możliwością emisji filmowej, medium, które dostarczało wiadomości za pomocą obrazu i dźwięku, było kino. I choć Kościół miał przez lata ambiwalentny stosunek do tego medium, to jednak zachęca do oglądania filmów o tematyce religijnej oraz tych, które promują dobro, prawdę i piękno ${ }^{69}$.

\subsection{Film JAKo ELEMENT KULTURY}

Kino, które swoim zasięgiem nie dorównuje dzisiejszemu zasięgowi telewizji, od dawna jednak było jednym ze składników kultury. Pozwalało dostrzec specyficzny sposób istnienia człowieka i wiążących go z innymi ludźmi szczególnych powiązań tworzących wspólnotę, ,określając międzyludzki i społeczny charakter bytu człowieka" ${ }^{\text {"70 }}$. Kino może

${ }^{65}$ Por. Papieska Komisja do Spraw Środków Społecznego Przekazu, Instrukcja duszpasterska Zjednoczenie i postęp..., dz. cyt., s. 291-292.

${ }^{66}$ Jan Paweł II, Środki społecznego przekazu pomostem pomiędzy wiarą i kultura, dz. cyt.

67 Zob. Jan Paweł II, Religia w środkach przekazu, dz. cyt., s. 310-315.

${ }^{68}$ Jan Paweł II, Kino nośnikiem kultury $i$ wartości, dz. cyt.

69 Więcej na ten temat: K. Pokorna-Ignatowicz, Kościót w świecie mediów..., dz. cyt., s. 27-29.

70 Jan Paweł II, Kino nośnikiem kultury $i$ wartości, dz. cyt. 
wpłynąć na rozwój pojedynczego człowieka, ale może także wpłynąć na ożywienie działalności kulturalnej parafii czy diecezji. Kino stało się przestrzenią wymiany kulturowej, dlatego też trzeba zabiegać, by produkcja filmowa odnosiła się z szacunkiem do każdego życia ludzkiego, wpływała pozytywnie na wspólnoty, a także zgodnie z prawdą przekazywała potrzeby i oczekiwania każdego człowieka ${ }^{71}$.

Kino to także produkcje animowane, o których Kościół pisze, że mogą być wartościowe i wpływać pozytywnie na rozwój człowieka, zwłaszcza młodego. Aby jednak produkcje te były wartościowe, potrzebna jest współpraca pomiędzy ośrodkami produkującymi filmy (także filmy animowane), a środowiskami troszczącymi się o przekaz orędzia religijnego ${ }^{72}$.

\subsection{FILM A BUDOWANIE JEDNOŚCI MIĘDZY NARODAMI}

Kościół zwraca uwagę, że media, w tym kino i telewizja, stanowią „jeden z najbardziej charakterystycznych akcentów współczesnej cywilizacji" ${ }^{73}$. Nowe technologie, które odkryły przed człowiekiem nowe perspektywy rozwoju, sprawiły, że człowiek stał się obywatelem świata mogącym uczestniczyć w nawet najodleglejszych wydarzeniach. Przekroczenie granic, dialog międzykulturowy i międzyreligijny, otworzyły przed ludźmi nowe perspektywy rozwoju: i własnego, i całych społeczeństw. W krajach, gdzie media sprawują swoją służbę sumiennie: rzetelnie informując, dostarczając wartościowej rozrywki, ucząc i bawiąc, „możemy mówić o prawdziwym przeobrażeniu społecznym i kulturalnym, którego skutki znajdują odbicie nawet w życiu religijnym" ${ }^{\prime 4}$. Trzeba dołożyć wszelkich starań, aby antagonizmy panujące wśród rządów i narodów nie wpływały na budowanie murów pomiędzy ludźmi i społecznościami. A media, w tym kino, telewizja, internet, jako dar Boży przyczyniały się do budowania społeczeństw, w którym prawda i godność człowieka będą fundamentem wszelkich działan.

\section{WNIOsKI}

Z przeprowadzonych analiz dokumentów Kościoła katolickiego wynika, że po soborze watykańskim II środki społecznego przekazu stały się jedną z ważniejszych metod ewangelizacji oraz wynalazkami techniki, które należało, dla dobra ludzkości, wesprzeć odpowiednimi regulacjami.

\footnotetext{
${ }^{71}$ Jan Paweł II, Kino nośnikiem kultury i wartości, dz. cyt.

${ }^{72}$ Por. Jan Paweł II, Religia $w$ środkach przekazu, dz. cyt.

${ }^{73}$ Paweł VI, Środki społecznego przekazu ważnymi elementami cywilizacji, dz. cyt.

${ }^{74}$ Paweł VI, Środki społecznego przekazu ważnymi elementami cywilizacji, dz. cyt.
} 
Analiza całościowa powyższych dokumentów prowadzi do kilku ważnych wniosków:

1. Wielokanałowość przekazu medialnego zmusiła Kościół katolicki do dostosowania form ewangelizacyjnych do nowych sposobów dystrybucji, w tym do przekazu telewizyjnego i filmowego.

2. Kościół podkreślał, że telewizja i film poprzez odpowiednie treści działają na rzecz człowieka i społeczeństw, dlatego też przekaz telewizyjny powinien być przede wszystkim ukierunkowany na rozwój jednostek.

3. Media odgrywają ważna rolę w procesie wychowania i edukacji młodych pokoleń. Współpraca pracowników mediów z rodzicami, $\mathrm{z}$ wychowawcami i kapłanami w trudnym i długim procesie wychowania młodych ludzi może przynieść wymierne korzyści w postaci przyszłych pokoleń ludzi ukształtowanych zgodnie z zasadami Ewangelii.

4. Media dają szansę ludziom na pokonywanie granic, na spotkania z przedstawicielami innych kultur i religii. Te spotkania dają możliwość współpracy z innymi, wymianę poglądów i pogłębienie wzajemnego zrozumienia. W tym wymiarze swojej działalności telewizja i film przekazują Dobrą Nowinę tam, gdzie jeszcze nikt jej nie słyszał.

5. Telewizja i film stają się także narzędziami kulturotwórczymi, które dają nowe możliwości tworzenia i prezentowania swojego dorobku na całym świecie, w tym dorobku stricte religijnego.

6. Papieże przestrzegają przed użyciem mediów w sposób niezgodny z misją, do której zostały powołane: manipulacja, podsycanie wzajemnej nienawiści, wykorzystywanie mediów jako narzędzi walki politycznej czy eksponowanie okrucieństwa, zła i wojen może prowadzić do wytworzeniu w odbiorcach fałszywego obrazu świata.

7. Zbytnie skupienie się na atrakcyjności przekazu może prowadzić do prezentowania zafałszowanego obrazu świata, to z kolei może skutkować nieprawdziwą wiedzą odbiorców na temat świata, w którym żyją.

8. Kościół przestrzega także przed komercjalizacją telewizji i filmu. Wykorzystanie mediów wyłącznie do powiększania kapitału poprzez prezentowanie treści pornograficznych, kłamstwa i zafałszowanego obrazu świata prowadzi do wykorzystywania widzów do partykularnych celów właścicieli mediów, niezgodnych z nauczaniem Kościoła.

Troska Kościoła katolickiego o przekaz, o media, ich twórców i ich odbiorców jest efektem troski Kościoła o człowieka, jego życie w prawdzie i budowanie wspólnoty opartej na mocnych fundamentach. Przeanalizowane dokumenty Kościoła i orędzia papieży są wyrazem zatroskania i chęci pomocy nie tylko ludziom tworzącym telewizję i inne media, ale także samym odbiorcom. „Film, później telewizja, wykorzystując równocześnie dźwięk i obraz, spowodowały nowe [...] konsekwencje w życiu indywidualnym i społecznym człowieka. [...] Wprowadzają wielki świat ludzkich spraw i problemów w zacisze domu rodzinnego, w prywatność życia"75.

${ }^{75}$ J. Chrapek CSMA, Współczesne techniki komunikowania nowym wyzwaniem dla Kościoła, w: Kościół a środki społecznego przekazu, pod red. J. Chrapka, Warszawa 1990, s. 15. 


\section{ZAKOŃCZENIE}

Kościół katolicki od początku powstania i rozwoju środków społecznego komunikowania zdawał sobie sprawę z ogromnych możliwości, które drzemią w przekazach telewizyjnych i filmach. Benedykt XVI, pisał, że media są "nowym areopagiem” współczesnego świata, wielkim forum, które [...] tworzy wspólnotę ${ }^{76}$. Takie pojmowanie mediów staje się wyzwaniem dla Kościoła - zajmując się problematyką mediów, musi on nie tylko wykorzystywać je do głoszenia Ewangelii, ale starać się wprowadzać ewangeliczne orędzie do „nowej kultury” medialnej, ukształtowanej przez współczesne środki przekazu, w tym także do „nowych języków, nowych technik, nowych postaw psychologicznych"77.

Jeżeli odniesiemy zalecenia Kościoła katolickiego dotyczące filmu i telewizji do obecnej struktury mediów, rodzi się pytanie, czy zasady te powinny być stosowane również do telewizji internetowych? Czy zalecenia te obowiązują także twórców i pracowników prywatnych telewizji internetowych? Ponadto warto w tym miejscu zadać jeszcze jedno pytanie: czy zaleceń Kościoła powinni przestrzegać także twórcy filmów zamieszczanych w internecie - na przykład w serwisie youtube.com? Zasady tworzone przez Kościół katolicki są uniwersalne. Czy są przestrzegane dziś, także w internecie? To pytanie pozostawiam otwarte.

\section{LITERATURA}

Baczyński A., Telewizja jako środek ewangelizacji, Kraków 1997.

Drożdż M., Media przestrzenia dialogu z czlowiekiem. Inspiracje soborowe w myśli Jana Pawła II, w: Inter mirifica. Dziedzictwo i perspektywy, red. A. Baczyński, M. Drożdż, M. Legan, Kraków 2013, s. 81-110.

Goban-Klas T., Media i komunikowanie masowe. Teorie i analizy prasy, radia, telewizji i Internetu, Warszawa 2009.

Grocholewski Z., Rola mediów w Kościele Katolickim, w: Media katolickie: szanse i zagrożenia, red. K. Bieliński, Toruń 2010, s. 13-17.

Komorowska J., Telewizja a wychowanie w rodzinie i zdrowie psychiczne dziecka, w: Kościót a środki społecznego przekazu, red. J. Chrapek CSMA, Warszawa 1990, s. 114-127.

Lis M., Edukacja medialna: ważny postulat "Inter mirifica”, w: Inter mirifica. Dziedzictwo i perspektywy, red. A. Baczyński, M. Drożdż, M. Legan, Kraków 2013, s. 43-66.

Lis M., Orędzia Papieskie na Światowe Dni Komunikacji Społecznej 1967-2002, Częstochowa 2002.

Media światem człowieka, red. M. Drożdż, I. Fiut, Kraków-Kielce 2009.

${ }^{76}$ Benedykt XVI, Z pomoca Ducha Świętego głosimy nadzieję. Orędzie na 32. Światowy Dzień Środków Społecznego Przekazu (1998), https://www.paulus.org.pl/235,32-sdssp-jan-pawel-ii-1998 (28.05.2018).

77 Por. Benedykt XVI, Z pomocą Ducha Świętego głosimy nadzieję, dz. cyt. 
Papieska Komisja do Spraw Środków Społecznego Przekazu, Instrukcja duszpasterska Zjednoczenie i postęp o środkach społecznego przekazu, zredagowana na polecenie Drugiego Watykańskiego Soboru Powszechnego, w: Kościół a kultura masowa, wybór tekstów i oprac. F. Adamski, Kraków 1987, s. 277-320.

Pokorna-Ignatowicz K., Kościół w świecie mediów. Historia - dokumenty - dylematy, Kraków 2002.

Wiśniewski P., Radiofonia i telewizja narzędzia służące realizacji misji Kościoła. Prawo i praktyka w Polsce 1989-2008, Lublin 2010. 